\title{
PERANAN GURU BIMBINGAN DAN KONSELING DALAM PEMBENTUKAN KARAKTER SISWA DI SMP NEGERI 36 PALEMBANG
}

\author{
Anisa Syahdana ${ }^{1}$, Nurlela ${ }^{2}$ \\ Universitas PGRI Palembang ${ }^{1}$ \\ Email: syahdanaanisa@gmail.com \\ Universitas PGRI Palembang ${ }^{2}$ \\ Email: nurlela@gmail.com
}

\begin{abstract}
ABSTRAK
Penelitian ini bertujuan untuk mengetahui peranan guru bimbingan dan konseling dalam pembentukan karakter disiplin siswa di SMP NEGERI 36 Palembang.Penelitian ini menggunakan pendekatan kualitatif deskriptif. Peneliti menggunakan metode pengumpulan data berupa wawancara dan dokumentasi penentuan informan dalam penelitian ini menggunakan teknik sampling purposive. Informan dalam penelitian ini yaitu wakil kesiswaan, guru wali kelas, guru bimbingan dan konseling dan satu orang siswa kelas VII. Hasil penelitian ini menunjukan peran guru bimbingan dan konseling dalam pembentukan karakter disiplin siswa cukup berjalan dengan baik. Guru bimbingan dan konseling berkolaborasi dengan wakil kesiswaan, guru wali kelas, dan orang tua untuk menyelesaikan permasalahan siswa yang kurang disiplin. Siswa yang kurang disiplin diberikan layanan konseling individual dan guru bimbingan dan konseling juga melakukan kunjungan kerumah siswa untuk mencari tahu faktor penyebab siswa tersebut kurang disiplin dan membicarakan permasalahan siswa disekolah kepada orang tua siswa.
\end{abstract}

Kata Kunci: Peran Guru Bimbingan Konseling, Pembentukan Karakter, Disiplin

\section{THE ROLE OF COUNSELING AND COUNSELING TEACHERS IN THE FORMATION OF STUDENT CHARACTERS IN SMP NEGERI 36 PALEMBANG}

\begin{abstract}
This study aims to determine the role of guidance and counseling teachers in building the disciplinary character of students in smp 36 palembang. This research uses a descriptive qualitative approach. This study uses from interview data collection methods and documentation. Determination of informants in this study using purposive sampling technique, the informants in this study are vice headmaster, class master, counseling teachers and one seventh grade student. The results of this study indicate that the rule of the counseling guidance teacher in bullding character of student discipline is running well. The guidance and counseling teachers collaborate with vice headmaster, classroom teachers and parents to solve student problems who are less disciplined. The students who less
\end{abstract}


disciplined are given individual counseling services and counseling guidance teachers also make visit to students tobe less disciplined and discuss student problems at school to the students parents.

\section{Keywords: Role Guidance Counseling Teachers, The Building Of, Disciplined Character}

\section{PENDAHULUAN}

Pendidikan adalah seluruh aktivitas atau upaya secara sadar yang dilakukan oleh pendidik kepada peserta didik terhadap semua aspek perkembangan kepribadian, baik jasmani dan rohani, secara formal, informal yang berjalan terus-menerus untuk mencapai kebahagian yang tinggi (baik insaniyah maupun ilahiyah). Pendidikan masa kini sangat di pengaruhi oleh masuknya kebudayaankebudayaan asing di Indonesia oleh karena itu perlunya guru bimbingan dan konseling mengarahkan siswa kearah kebudayaan yang sesuai dengan bangsa kita yaitu kebudayaan yang berdasarkan pancasila. Globalisasi pada masa sekarang banyak mempengaruhi siswa, misalnya dengan penggunaan alat komunikasi.Pengaruh globalisasi ini ada dampak negatifnya dan ada dampak positifnya. Dampak positifnya dapat mempengaruhi siswa berpikir maju dan bersaing ilmu pengetahuan dengan bangsa lain, tapi dari segi negatifnya akan mempengaruhi siswa ke karakter yang tidak baik.

Karakter tidak lain merupakan perilaku, kepribadian atau kebiasaan perilaku yang di tunjukkan oleh siswa. Karakter siswa yang kurang baik tidak dapat dibiarkan tetapi harus dapat diatasi melalui upaya peranan guru bimbingan dan konseling di sekolah. Berbagai makna mengenai pendidikan karakter. Zubaedi (2011 :25) menyatakan sebagai berikut : pendidikan karakter adalah pendidikan budi pekerti plus, yang intinya merupakan program pengajaran yang bertujuan mengembangkan watak dan tabiat peserta didik dengan cara menghayati nilainilai dan keyakinan masyarakat sebagai kekuatan moral dalam hidupnya melalui kejujuran, dapat dipercaya, disiplin, dan kerja Sama yang menekankan ranah afektif (perasaan atau sikap) tanpa meninggalkan ranah Kognitif (berpikir rasional), ranah skill (keterampilan,terampil mengolah data, mengemukakan pendapat, dan kerja sama) Sekolah sebagai salah satu lembaga yang menyelenggarakan pendidikan formal mempunyai peranan yang amat penting 
dalam usaha mendewasakan anak dan menjadikannya sebagai anggota masyarakat yang berguna.Hal ini berarti sekolah turut pula bertanggung jawab tercapainya suatu tujuan, yang telah ditetapkan.

Dewasa ini banyak perilaku kriminal yang dilakukan oleh siswa, seperti yang terjadi di SMP Negeri 36 Palembang, sebagian siswa kelas VII memiliki karakter disiplin yang kurang baik, siswa sering sekali melakukan tindakan kenakalan seperti berkelahi dengan teman satu sekolah, atau siswa dari sekolah lain, membuat keributan dengan guru di sekolah. Siswa juga sering terlibat pergaulan di luar batas seperti tidak menggunakan pakaian seragam, terlambat datang ke sekolah untuk mengikuti pelajaran, suka bermain dengan teman saat guru sedang belajar, suka membolos sekolah, jarang masuk sekolah sampai seminggu lebih, tidak mengerjakan pekerjaan rumah, dan sebagainya. Informasi ini peneliti dapatkan langsung dari guru bimbingan dan konseling di SMP Negeri 36 Palembang. Berdasarkan permasalahan tersebut peranan bimbingan dan konseling dalam pembentukan karakter kepada siswa di sekolah sangat penting karena perkembangan dunia pendidikan yang sangat pesat saat ini, dimana masing- masing sekolah berusaha membentuk karakter siswa yang perilaku yang tidak baik di ubah menjadi perilaku yang baik walaupun memang sudah dari karakter siswa tersebut yang terbentuk dari lingkungan keluarga nya. Di sini bimbingan dan konseling muncul sebagai solusi bagi sekolah dalam membantu mengarahkan siswa nya untuk menjadi perilaku yang baik di sekolah dan masyarakat.

\section{LANDASAN TEORI}

Akhmad Muhaimin Azzet (2011:10) menjelaskan, "Bimbingan dan konseling adalah upaya dalam memberikan pelayanan bantuan kepada anak didik agar mampu dan berkembang secara optimal. Pelayanan bantuan ini bisa dilakukan kepada anak didik secara perorangan atau kelompok.Bimbingan dan konseling disekolah di selenggarakan oleh guru bimbingan dan konseling.Peraturan Menteri Pendidikan dan Kebudayaan Tentang Bimbingan dan Konseling Pada Dasar dan Pendidikan Menengah Nomor 111 Tahun 2014 
pasal 1 butir 4 menjelaskan bahwa, "Guru Bimbingan dan Konseling adalah pendidik yang berkualifikasi akademik minimal sarjana pendidikan (S-1) dalam bidang Bimbingan dan Konseling dan memiliki kompetensi di bidang Bimbingan dan Konseling”. Guru bimbingan dan konseling perlu mengambil peran dalam pendidikan karakter melalui layanan bimbingan dan konseling, dengan adanya guru bimbingan dan konseling dapat membantu siswa memahami diri dan lingkungannya, mampu mengarahkan diri, menyesuaikan diri sehingga menjadi siswa yang memiliki karakter yang baik. Tujuan penelitian adalah untuk mengetahui peranan guru bimbingan dan konseling dalam pembentukan karakter displin siswa di sekolah.

\section{METODOLOGI PENELITIAN}

Bungin (2011:78) menjelaskan "Objek penelitian yang fokus dan fokus penelitian, yaitu apa yang menjadi sasaran. Yang menjadi objek dalam penelitian ini adalah bagaimana peranan guru bimbingan dan koseling dalam pembentukan karakter disiplin siswa. Dalam pengambilan informan dilakukan dengan cara purposive sampling. purposive Sampling adalah teknik penentuan sampel dengan pertimbangan tertentu sugiono (dalam Ferdiansyah, 2015:47). Informan dalam penelitian ini yaitu wakil kepala sekolah bidang kesiswaan, guru bimbingan dan konseling, guru wali kelas, dan satu orang siswa kelas Vll SMP Negeri 36 Palembang. Dalam penelitian ini, yang digunakan oleh peneliti adalah kualitatif deskriptif, Ferdiansyah (2015:49) menjelaskan,"bahwa penelitian kualitatif deskriptif sebagai human instrumen, berfungsi menetapkan fokus penelitian, memilih informasi sebagai sumber data, melakukan pengumpulan data, menilai kualitas data, analisis data, menafsirkan data dan membuat kesimpulan atas temuannya. Teknik pengumpilan data pada penelitian ini adalah wawancara, observasi, dan dokumentasi. 


\section{HASIL PENELITIAN DAN PEMBAHASAN}

\section{HASIL PENELITIAN}

Berdasarkan hasil wawancara yang dilakukan dan diperoleh peneliti dengan cara terjun kelapangan sehingga mendapatkan informasi sebagai gambaran data untuk hasil akhir dari penelitian ini. Sebelum peneliti melakukan wawancara, di sini peneliti terlebih dahulu melakukan kegiatan observasi ke sekolah yang bertujuan sbagai data penukung dalam kegiatan penelitian. Kegiatan wawancara ini dilakukan dengan beberapa pihak yaitu Wakil Kepala Sekolah Bidang Kesiswaan, Guru Wali Kelas, Guru Bimbingan dan Konseling, dan siswa.

Adapun hasil wawancara Wakil Kepala Sekolah Bidang Kesiswaan yaitu antara lain:

"Peran saya sebagai Wakil Kesiswaan dalam pembentukan karakter disiplin siswa. Saya menanamkan nilai-nilai kedisiplinan kepada siswa dengan mensosialisasikan budaya kedisiplinan kepada siswa, memberikan keteladanan dalam disiplin serta menyampaikan manfaat dari berdisiplin. Di sekolah ini saya juga menerapkan sistem poin siswa yang kurang disiplin akan dikenakan sanski poin yang kurang disiplin akan dikenakan sanski poin. Siswa yang melakukan pelanggaran disiplin seperti tidak masuk sekolah tanpa izin, minggat, berpakaian tidak rapi, membawa hp, saat disiplin kegiatan belajar mengajar, Untuk mengurangi pelanggaran perlu adanya kerjasama dari Wakil Kesiswaan antara Wali Kelas dengan Guru Bimbingan dan Konseling. Untuk mengatsi pernasalahan siswa yang kurang disiplin agar kedepannya tidak ada lagi siswa yang melakukan pelanggaran disiplin."

Adapun hasil wawancara yang dilakukan oleh peneliti dengan wali kelas antara lain :

"Tujuan Wali Kelas tentunya sama dengan tujuan orang tua yaitu mendidik anak- anaknya menjadi anak yang cerdas dan berakhlak. Saya sebagai wali siswa sering mendiskusikan dengan anak didik saya seperti menentukan kesepakatan berkaitan dengan penanaman nilai misalnya menanamkan kepada anak didik mengenai kedisiplinan hadir. Dengan cara memberikan informasi kepada anak didik bahwa setiap siswa dikelas kalau tidak hadir 
wajib menginformasikan kepada wali kelas baik melalui surat atau pesan singkat ditelpon. Apabila terdapat salah satu siswa yang alpha saya akan melakukan pendekatan dengan siswa untuk mencari tahu penyebabnya, Lalu saya berikan arahan. Apabila tidak ada perubahan pada anak didik saya, maka saya akan bekerjasama dengan Guru Bimbingan dan Konsling untuk mencari penyelesaiankan permasalahan anak tersebut."

Selanjutnya hasil wawancara yang peneliti peroleh dari Guru Bimbingan dan Konseling antara lain:

"Peran Guru Bimbingan dan Konseling sebenarnya menanamkan karakter disiplin siswa. Guru Bimbingan dan Konseling dan orang tua berperan dalam pembentukan karakter disiplin anak, Guru Bimbingan dan Konseling dan orang tua harus bekerja sama agar anak memiliki karakter yang disiplin baik. Peran Guru Bimbingan dan Konseling untuk mengatasi masalah mengenai siswa yang bermasalah terkait dengan kedisiplinan seperti yang sering terjadi disekolah ini, siswa sering membolos tanpa memberikan surat izin (Alpha), dan ada juga siswa yang berkelahi. Siswa yang melakukan pelanggaran disiplin biasanya saya akan memanggil siswa tesebut untuk keruang Bimbingan dan Konseling. Diruang Bimbingan dan Konseling saya memberikan layanan konseling individual dengan begitu saya bisa tau apa yang memyebabkan siswa tersebut bermasalah setelah dan penyebabnya lalu mencari jalan penyelesainnya. Apabila anak tersebut sudah diberikan layanan konseling individual masih saya melakukan home visit atau kunjungan kerumah siswa yang bermasalah tersebut untuk mencari tahu penyebab- penyebab siswa bermasalah dari keluarga siswa." Adapun hasil wawancara yang di peroleh dari siswa kelas VII 9 antara lain : "Di sekolah ini pelanggaran disiplin yang sering terjadi seperti terlambat datang ke sekolah, tidak memakai seragam sekolah dengan lengkap, berkelahi dan membolos. Saya pernah melanggar tata tertib sekolah seperti membolos. Saya membolos $3 x$ berturut - turut tidak memberikan surat izin keguru. Lalu saya dipanggil wali kelas, wali kelas bertanya kepada saya penyebab saya bolos sekolah, kemudian wali kelas menyuruh saya keruang 
Bimbingan dan Konseling Guru Bimbingan dan Konseling menyuruh saya menceritakan penyebab saya membolos, setelah itu guru Bimbingan dan Konseling memberikan menasehati kepada saya, saya sanski poin dan surat pernyataan bahwa saya tidak akan mengulangi kesalahan saya lagi. Kalau saya mengulangi kesalahan saya lagi guru bimbingan dan konseling akan memberikan surat panggilan kepada orang tua saya. Untuk datang kesekolah."

Jadi, dari hasil wawancara yang telah diperoleh dari Wakil Kepala Sekolah Bidang Kesiswaan, Guru Wali Kelas dan Guru Bimbingan dan Konseling mengenai peranan guru bimbingan dan konseling dalam pembentukan karakter disiplin siswa yaitu dapat disimpulkan yaitu antara lain:

1. Harus adanya kerjasama yang baik antara wakil kesiswaan, guru bimbingan dan konseling dan guru wali kelas untuk menyelesaikan masalah siswa terkait dengan pelanggaran disiplin.

2. Guru bimbingan dan konseling memberikan layanan konseling individual kepada siswa yang melakukan pelanggaran disiplin.

3. Guru bimbingan dan konseling bekerja sama dengan orang tua siswa untuk menyelesaikan permasalahan yang dialami siswa.

4. Guru bimbingan dan konseling melakukan home visit untuk mengatasi siswa yang permasalahan.

\section{PEMBAHASAN}

\section{Peran Guru Bimbingan dan Konseling Dalam Pembentukan Karakter} Siswa.

Pembentukan karakter disiplin siswa menjadi salah satu tugas dari guru bimbingan dan konseling, sehingga guru bimbingan dan konseling berperan sebagai pendidik dalam pembentukan karakter disiplin siswa. Guru bimbingan dan konseling memiliki peran aktif dalam pembentukan karakter siswa seperti saat ini banyak siswa yang karakter disiplinnya lemah sehingga perlu dilakukan bimbingan di sekolah. Pembinaan karakter sesungguhnya sangat penting dalam membangun moral anak bangsa. Pembetukan karakter 
disiplin siswa di SMP NEGERI 36 Palembang guru bimbingan dan konseling bekerja sama dengan wakil kesiswaan, guru wali kelas serta orang tua untuk mengatasi siswa yang kurang disiplin. Guru bimbingan dan konseling dalam pembentukan karakter siswa terfokus pada pemberian layanan bimbingan dan konseling pada siswa yang bermasalah dengan memberikan layanan konseling individual serta melakukan kunjungan kerumah siswa.Dalam pembentukan karakter disiplin siswa orang tua juga berperan. Guru bimbingan dan konseling dan orang tua harus bekerja sama dalam pembentukan karakter siswa agar karakter disiplin siswa menjadi lebih baik. Selain itu guru wali kelas juga berperan dalam pembentukan karakter disiplin siswa, guru wali kelas menjadi pendamping dan pengawas pelaksanaan pendidikan karakter di kelas. Wali kelas selalu mengabsen kehadiran siswa apabila ada salah satu anak didiknya yang tidak hadir tanpa keterangan maka wali kelas akan bekerja sama dengan guru bimbingan dan konseling untuk mencari tahu penyebabnya. Dalam pembentukan karakter disiplin siswa guru bimbingan dan konseling berkolaborasi dengan wali kelas, guru bimbingan dan konseling harus siap menerima alih tangan dari wali kelas setiap harinya. Wali kelas harus menindak lanjuti masalah siswa yang kurang disiplin wali kelas akan membicarakan permasalahan anak didiknya dengan guru bimbingan dan konseling, guru bimbingan dan konseling menindak lanjuti dengan memberikan layanan konseling individual.

Jadi kesimpulan dari penelitian ini dalam pembentukan karakter yaitu guru bimbingan dan konseling berkolaborasi dengan wali kelas, wakil kepala sekolah bidang kesiswaan dan harus siap menerima alih tangan dari wali kelas nya. Guru bimbingan dan konseling bekerja sama dengan orang tua nya dalam pembentukan karakter siswa menjadi lebih baik karena peran orang tua sangat lah penting dalam pembentukan karakter siswa tersebut. Guru bimbingan dan konseling memberikan layanan konseling individual bagi siswa yang bermasalah agar bisa mencari tahu penyebabnya. 


\section{KESIMPULAN}

Berdasarkan hasil penelitian hasil penelitian yang dilakukan peneliti pada tanggal 1 Agustus-14 Agustus dapat ditarik kesimpulan antara lain :

1. Peran guru bimbingan dan konseling dalam pembentukan karakter disiplin siswa guru bimbingan dan konseling mengadakan kerja sama dengan wali kelas, wakil kesiswaan dan orang tua untuk menyelesaikan masalah siswa kurang disiplin.

2. Guru bimbingan dan konseling memberikan layanan konseling individual dan melakukan home visit untuk menyelesaikan permasalahan siswa yang kurang disiplin.

3. Peran guru bimbingan dan konseling dalam pembentukan karakter disiplin siswa mempunyai tugas dan tanggung jawab yang sangat penting dalam pembentukan karakter disiplin siswa.

\section{DAFTAR PUSTAKA}

Arsyad, Wahyuni Annisa. 2019. Komunikasi Antarpribadi Guru Dan Siswa Dalam Meningkatkan Kedisiplinan Siswa Di Sma muara Lawa Kabupaten Kutai Barat. ISSN 2502- 5961.

Atnawi. 2019. Pengaruh Kedisplinan Terhadap Tingkat Prestasi Belajar Siswa DI Sdn Murtajih Pamekasan.ISSN. 23550104.

Azzet, Akhmad Muhaimin. 2011. Bimbingan dan konseling di sekolah. Jogjakarta:Ar-Ruzz Media.

Arif, Bambang Samsul. 2020. Implementasi Pengembangan Keberagamaan Peserta Didik Di SMA Muahammdiyah Cipanas Dan Pengaruhnya Terhadap Pembentukan Karakter. VOL: 09/NO: 01 Februari 2020

Bungin, Burhan. 2011. Penelitian kualitatif, komunikasi, ekonomi, kebijakan public,dan ilmu sosial lainnya. Kencana.

Cahyani, Indri. 2019. Pendidikan Multikultural Sebagai Pembentukan Karakter Peserta Didik. Vol.2 No.2 Juli2019

Ferdiansyah. 2015. Dasar penelitian kualitatif. Herya Media.

Fiara, Ana. 2019. Analisis Faktor Penyebab Perilaku Tidak Displin Pada Siswa Smp Negeri 3 Banda Aceh.

Heiriyah, Ainun. 2019. Strategi Guru Bimbingan dan Konseling Dalam Mengatasi Siswa Yang Tidak Displin Di Smp Negeri 17 Banjarmasin. 
Juntika, Nurihsan Achmad. 2014. Bimbingan dan konseling dalam berbagai latar kehidupan.Bandung: PT RefikaAditama.

Juntika, Nurihsan Achmad. 2016. Landasan Bimbingan dan Konseling. Bandung: PT Remaja Rosdakarya.

Kesuma, Dharma. 2018. Pendidikan karakter kajian teori dan praktik disekolah.Bandung: PT Remaja Rosdakarya.

Kurniawan, Syamsul. 2017. Pendidikan karakter, konsepsi \& implementasinya secara terpadu di lingkungan keluarga, sekolah, perguruan tinggi \& masyarakat. Yogyakarta.

Kusmanto. 2013. Peran Badan Permasyarakatan Daerah Dalam Meningkatkan Partisipasi Politik Masyarakat. Jurnal Ilmu Pemerintahan dan Sosial Politik.Volume 1, Nomor 1, Halaman 39-47, ISSN 2549-1660

Putri, Revita Nova. 2018. Analisis Tindak Indisipliner Siswa Smp Negeri.Volume 2 Nomor 2 Maret 2018.

Rosada, Danni Ulfa. 2019. Peran Layanan Bimbingan Dan Konseling Dalam Menanamkan Nilai-Nilai Karakter Siswa Di Sekolah Dasar.ISSN 27145972.

Risma. 2020. Pengaruh Layanan Bimbingan Kelompok Terhadap Peningkatan Kedisplinan Siswa.Volume 4 nomor 1 januari 2020.

Sugiyono. 2017. Metodologi penelitian kuantitatif kualitatif.Bandung: Alfabeta.

Suhardono, Edy. 2018. Teori Peran Konsep, Derivasi dan Implikasinya.PT Gramedia Pustaka Utama Jakarta.

Tu'u. Tulus. 2010. Peran Displin Pada Perilaku Dan Prestasi Siswa. Jakarta: PT Grasindo.

Tohirin. 2014. bimbingan dan konseling di sekolah dan madrasah. Jakarta: Rajawali Pers.

Undang-undang Republik Indonesia Nomor 20 Tahun 2003 tentang sistem pendidikan nasional.

Zubaedi. 2011. Desain pendidikan karakter, konsepsi dan aplikasinya dalam lembaga pendidikan. Jakarta: Kencana Prenada Media Group. 